\section{The non-equilibrium landscape of the Sierra Nevada, California:}

\author{
M.K. Clark, G. Maheo, J. Saleeby, and K. Farley, California \\ Institute of Technology, Mailstop 100-23, Pasadena, California
}

91125, USA, mclark@gps.caltech.edu

We thank H.F. Garner for calling attention to an important factor governing fluvial erosion: the role of variable stream discharge caused by climatic fluctuations. We agree that climatic variations affect erosion rates and stream morphology by altering stream discharge, altering bed state such as armoring of channel bottoms and changing sedimentary flux, and can vary local base levels during glacial/interglacial cycles. These processes have most likely played a role in changing river profile form and erosion rates to some degree at various times throughout the Cenozoic in the Sierra Nevada. However, Garner argues that climatically driven changes in erosion rate led to elevation change through isostatic adjustment without any need to call on tectonic forces to explain the modern elevation of the range. This is where we disagree.

An increase in mean elevation of the range due to isostatic adjustment to erosion alone requires incision of narrow river valleys into a relatively unincised, elevated surrounding area (e.g., England and Molnar, 1990; Whipple et al., 1999). Our estimate of incision of river canyons into the relict landscape relied on interpretation of longitudinal river profiles. Dominant physical erosional processes in bedrock rivers, such as plucking, abrasion, and cavitation, along with other factors that control channel incision rate, such as channel width, channel sinuosity, and sediment supply, combine in complex ways that affect the longitudinal channel profile; however, it has long been recognized that longitudinal channel profiles exhibit a power-law scaling relationship between local channel slope and contributing drainage area (e.g., Hack, 1973; Flint, 1974; Howard and Kerby, 1983; Wobus et al., 2006). River profile reconstruction and identification of relict landscape surfaces allowed us to determine that the total volume of incision into the relict landscape has been small. While the limited magnitude of this incision undoubtedly drove some minor increase in elevation, it is unlikely to have driven kilometers of isostatically-driven elevation change, even with a thin elastic lithosphere (e.g., Clark et al., in press; Whipple et al., 1999).

Erosion-rate data support the idea that river channels are responsive to both changes in rock uplift rate and changes in precipitation (e.g., Snyder et al., 2000; Lave and Avouac, 2000; Reiners et al., 2003; Wobus et al., 2003; Thiede et al., 2005). We related changes in erosion rate in the Sierra Nevada to an acceleration of channel incision due to an increase in the elevation of the range that must have occurred to form the canyons cut into the relict landscape that we observe today. This landscape form can be uniquely associated with elevation increase simply because the downcutting of extremely deep valleys into a low-relief landscape formed near sea level requires an increase in elevation. Changes in base level by $100 \mathrm{~m}$ due to glacial/interglacial fluctuations are small on the scale of the total elevation change considered by our analyses $(2500 \mathrm{~m})$.

Our model assumes that upstream drainage area is a proxy for discharge, which, among other things, assumes that precipitation is constant in space and time. It is possible that the modern Sierra Nevada receives more precipitation today than in early or mid-Cenozoic time due to an increase in orographic precipitation as the mountain range grew, or changes in moisture yield due to atmospheric circulation and temperature changes. The change from a drier to more humid climate that Garner suggests could potentially have decreased the channel relief on the relict landscape from mid-Cenozoic time to the present. Therefore, using estimates of channel parameters from the present relict landscape may underestimate predictions of trunk stream paleo-relief. However, the lack of change in longterm erosion rates recorded by helium ages and the agreement between long-term and short-term erosion rates for the relict landscape do not support a large-magnitude erosional event that would be required to significantly reduce the relief on the relict landscape. Also, the excellent agreement between the independently calculated Kern and Kings river paleo-crestal elevations, despite different orientations to prevailing wind direction and differences in modern precipitation patterns, argues that changes in precipitation are unlikely to have influenced paleo-channel parameter estimates.

The notion that the Sierra Nevada has been undergoing isostatic uplift due to erosional unloading since Jurassic time stems from obsolete models of a thick felsic root having formed beneath the batholith (Bateman and Eaton, 1967; Carder, 1973; Pakiser and Brune, 1980). Average crustal thicknesses in the southern Sierra Nevada are inadequate to explain the high elevation of the range by simple Airy isostasy (Fliedner et al., 1996, 2000). Slow seismic wavespeeds beneath the range, changes in volcanic chemistry, and petrologic changes in deeply sourced xenoliths all point to a major change in deep lithospheric composition in late Miocene or Pliocene time that would have led to a decrease in the average density of the lithosphere and a resulting elevation increase (Fliedner et al., 1996, 2000; Ducea and Saleeby 1996, 1998; Manley et al., 2000; Farmer et al., 2002). The regionally consistent pattern of low relief, except in glaciated areas, on the subEocene relict landscape and its slow denudation as recorded in our helium data further refutes the notion of kilometers of isostatic uplift due to erosional unloading since Jurassic time. We suggest that all of the available evidence points to a predominately tectonic, rather than climatic-isostatic, source of elevation change for the southern Sierra Nevada during late Cenozoic time. 


\section{REFERENCES CITED}

Bateman, P.C., and Eaton, J.P., 1967, Sierra Nevada batholith: Science, v. 158, p. 1407-1417. Clark, M.K., Royden, L.H., Whipple, K.X., Burchfiel, B.C., Zhang, X., and Tang, W., Deformation of a regional low-relief landscape (erosion surface) in eastern Tibet: Journal of Geophysical Research, Earth Surface (in press).

Carder, D.S., 1973, Trans-California seismic profile, Death Valley to Monterey Bay: Seismological Society of America Bulletin, v. 63, p. 571-586.

Ducea, M.N., and Saleeby, J.B., 1996, Buoyancy sources for a large, unrooted mountain range, the Sierra Nevada, California: Evidence from xenolith thermobarometry: Journal of Geophysical Research, v. 101, no. B4, p. 8229-8244, doi: 10.1029/95JB03452.

Ducea, M.N., and Saleeby, J.B., 1998, A case for delamination of the deep batholithic crust beneath the Sierra Nevada, California: International Geology Review, v. 133, p. 78-93

England, P., and Molnar, P., 1990, Surface uplift, uplift of rocks, and exhumation of rocks: Geology, v. 18, p. 1173-1177, doi: 10.1130/0091-7613(1990)018<1173: SUUORA $>2.3 . \mathrm{CO} ; 2$.

Farmer, G.L., Glazner, A.F., and Manley, C.R., 2002, Did lithospheric delamination trigger Late Cenozoic potassic volcanism in the southern Sierra Nevada, California?: Geological Society of America Bulletin, v. 114, no. 6, p. 754-768, doi: 10.1130/0016-7606(2002)114<0754:DLDTLC>2.0.CO;2.

Fliedner, M.M., Ruppert, S., and Working Group, S.S.C.D., 1996, Three-dimensional crustal structure of the southern Sierra Nevada from seismic fan profiles and gravity modeling: Geology, v. 24, p. 367-370, doi: 10.1130/0091-7613(1996)024<0367: TDCSOT>2.3.CO;2.

Fliedner, M.M., Klemperer, S.L., and Christensen, N.I., 2000, Three-dimensional seismic model of the Sierra Nevada arc, California, and its implications for crustal and upper mantle composition: Journal of Geophysical Research, v. 105, no. B5, p. 10,899-10,921, doi: 10.1029/2000JB900029.

Flint, J.J., 1974, Stream gradient as a function of order, magnitude, and discharge: Water Resources Research, v. 10, no. 5, p. 969-973.

Hack, J.T., 1973, Stream profile analysis and stream-gradient index: U.S. Geological Survey Journal of Research, v. 1, no. 4, p. 421-429.

Howard, A.D., and Kerby, G., 1983, Channel changes in badlands: Geological Society of America Bulletin, v. 94, p. 739-752, doi: 10.1130/0016-7606(1983)94<739: $\mathrm{CCIB}>2.0 . \mathrm{CO} ; 2$.
Lave, J., and Avouac, J.-P., 2000, Fluvial incision and tectonic uplift across the Himalayas of central Nepal: Journal of Geophysical Research, v. 105, no. B3, p. 5735-5770, doi: 10.1029/1999JB001893, doi: 10.1029/1999JB900292.

Manley, C.R., Glazner, A.F., and Farmer, G.L., 2000, Timing of volcanism in the Sierra Nevada of California: Evidence for Pliocene delamination of the batholithic root? Geology, v. 28, no. 9, p. 811-814, doi: 10.1130/0091-7613(2000)028<0811: TOVITS $>2.3 . \mathrm{CO} ; 2$

Pakiser, L.C., and Brune, J.N., 1980, Seismic models of the root of the Sierra Nevada: Science, v. 210, 4474, p. 1088-1094.

Reiners, P.W., Ehlers, T.A., Mitchell, S.G., and Montgomery, D.R., 2003, Coupled spatial variations in precipitation and long-term erosion rates across the Washington Cascades: Nature, v. 426, p. 645-647, doi: 10.1038/nature02111.

Snyder, N., Whipple, K., Tucker, G., and Merritts, D., 2000, Landscape response to tectonic forcing: DEM analysis of stream profiles in the Mendocino triple junction region, northern California: Geological Society of America Bulletin, v. 112, p. 1250-1263, doi: 10.1130/0016-7606(2000)112<1250:LRTTFD>2.3.CO;2.

Thiede, R.C., Arrowsmith, J.R., Bookhagen, B., McWilliams, M.O., Sobel, E.R., and Strecker, M.R., 2005, From tectonically to erosionally controlled development of the Himalayan orogen: Geology, v. 33, no. 8, p. 689-692, doi: 10.1130/G21483.1.

Whipple, K.X., Kirby, E., and Brocklehurst, S.H., 1999, Geomorphic limits to climateinduced increases in topographic relief: Nature, v. 401, no. 6748, p. 39-42, doi: $10.1038 / 43375$.

Wobus, C., Hodges, K.V., and Whipple, K.X., 2003, Has focused denudation sustained active thrusting at the Himalayan topographic front?: Geology, v. 31, p. 861-864, doi: 10.1130/G19730.1.

Wobus, C., Whipple, K.X., Kirby, E., Snyder, N., Johnson, J., Spyropolou, K., Crosby, B., and Sheehan, D., 2006, Tectonics from topography; Procedures, promise and pitfalls, in Willett, S.D., Hovius, N., Brandon, M.T., and Fisher, D., eds., Tectonics, climate, and landscape evolution: Geological Society of America Special Paper 398 , p. 55-74.

Manuscript accepted 27 January 2006; published online April 2006. 